\title{
The ANIMO Decalogue for a Slow Medicine care: the general recommendations of the nurses of internal medicine for a sober, respectful and equitable care
}

\author{
Gabriella Bordin, ${ }^{1}$ Claudia Ganzini, ${ }^{2}$ Mariapaola Lince, ${ }^{3}$ Lucia Lucci, ${ }^{4}$ Marilisa Martini,,${ }^{5}$ Giovanna Pentella, ${ }^{6}$ \\ Nicoletta Postal, ${ }^{7}$ Annunziata Zuccone, ${ }^{8}$ Claudia Gatta ${ }^{9}$ \\ ${ }^{1} \mathrm{CPSE}$ - ULSS 8 Asolo (TV); ${ }^{2} \mathrm{CPSE}$ - Ospedale atisana/bassa friulana, Udine; ${ }^{3} \mathrm{CPSE}$ - AO Santa Maria Nuova, Reggio \\ Emilia; ${ }^{4} \mathrm{CPSE}$ - Ospedale V. Fazzi, Lecce; ${ }^{5}$ Referente rapporti con le regioni - Anìmo; ${ }^{6} \mathrm{CPSE}$ - Ospedale Fatebenefratelli, \\ Napoli; ${ }^{7} \mathrm{CPSE}$ - APSS Trento; ${ }^{8} \mathrm{CPSE}$ - Ospedale San Donato, USL 8 Arezzo; ${ }^{9} \mathrm{CPSE}$ - ASL BI, Biella, Italy
}

\begin{abstract}
Following the lead of Slow Medicine, the Association of Nurses of Internal Medicine (ANIMO) saw the opportunity to build, through an analysis of the professional practice, an alliance between health professionals and citizens in order to support and facilitate informed choices. From this revision emerged The Decalogue, a document which summarizes the fundamental pillars of the slow nursing to guarantee a sober respectful and equitable care during the hospitalization.
\end{abstract}

\section{Introduction}

The Association of Nurses of Internal Medicine (ANİMO) has been involved, within other nursing associations, to participate in the initiative called Slow Medicine by the Federation of the Italian nursing colleges (IPASVI).

The participation in this project has raised a lot of interest, which fully embodies the ethical code ${ }^{1}$ and the nurse professional profile. ${ }^{2}$ This interest stems not only from the sharing of the need to counter the inappropriateness (of actions and prescriptions) from which disadvantages derive both in terms of increased risks for the patient and in terms of wasted resources,

Correspondence: Gabriella Bordin, CPSE - ULSS 8 Asolo (TV), Italy.

Tel.: +39.339.6690866. E-mail: g.bordin@libero.it

Key words: Slow Medicine; nursing; decalogue.

Acknowledgments: under the auspices of IPASVI National Federation, Slow Medicine, Federation of Association of Hospital Doctor on Internal Medicine (FADOI).

See online Appendix for additional Authors.

Received for publication: 1 July 2014.

Revision received: 8 September 2014.

Accepted for publication: 3 October 2014.

This work is licensed under a Creative Commons Attribution NonCommercial 3.0 License (CC BY-NC 3.0).

CCopyright G. Bordin et al., 2015

Licensee PAGEPress, Italy

Italian Journal of Medicine 2015; 9:279-280

doi:10.4081/itjm.2015.525 but also from the opportunity of comparison created by enlarging this project to other health professions.

For nurses it opens the opportunity to build, through a review of our professional practice, an alliance between health professionals and people.

The aim of these alliances is to support and to facilitate informed choices.

As nurses, even if the prescription unsuitability concern us only relatively, with a closer look we can evaluate the inadequacy of... rather than... that specific person. As basic essence of the reasoning, we have the responsibility to highlight and consider, during the activity, the alternative and the specificity of the person we are caring of, his needs within a life project that is nearing the end: it is perhaps the only way to avoid doing meaningless things (e.g., programming plans for mobilization in patients in the terminal phase).

Search for the meaning of things refers to an action that has the stem definitely anchored in the soil of sciences but it has as directive the search for the meaning, for the person's significance, for the people in front of us.

In this regard therefore it becomes critical thinking in an interdisciplinary perspective and opening a dialogue not only with the other nursing associations but also with medical scientific societies and professionals with whom we are working daily, with common objectives, for the same patient. Another important consideration has risen up from the question: What does it mean being a slow nurse and what does it mean deliver a sober, respectful and equitable assistance?

ANİMO has tried to answer the question with a Decalogue, in the wake of what has been proposed by FADOI, ${ }^{3}$ demonstrating the sharing of basic values and guidelines of daily work that unifies the two scientific societies, a document that invites the individual practitioner to stop and think: about the main objective of our 
discipline, which is not healing from illness but the resumption of the patient's maximum autonomy and ability to manage his state of health; about strategies that we have to put in place, from evidence-based practices to communicative ones, from education to customization of the interventions; ${ }^{4}$ about the crucial moments of the path of a patient hospitalized in medicine units: the reception, the management of drug therapy, ${ }^{5}$ the discharge, ${ }^{6}$ and everything that can be done by the nurse in a sober, respectful and legitimate way in the last stages of a person's life. ${ }^{7,8}$ In effect, a considerable number of people die in hospital ${ }^{9,10}$ and the care of terminally patient need of a careful consideration and a change of paradigm in relation to the classical model of assistance provided to the acute hospitalized patient.

\section{The Decalogue}

i) You must identify, during the reception in the hospital, the knowledge of the patient and of his family about the health condition and about their expectations regarding the care objectives, identifying potential improper requests.

ii) You must inform and involve the person in the care process and in the choices which concern him, you must guarantee times, spaces and adequate communication behaviors discussing also with him about which care objectives can be realistically achieved.

iii) You must guarantee inside the team an adequate communication in order to convey all the information regarding the patient and his care project.

iv) You must personalize the care interventions according to the real needs of the patient, to his principles and preferences, and also to the potential risks.

v) You must prioritize, while planning the care interventions, the recovery of the autonomy of the patient in the management of his health.

vi) You must make interventions based on the best available knowledge, you must say explicitly which objectives can be realistically pursued.

vii) You must cooperate with the physician on the assessment of the therapy and on the identification of problems related to the self-management of it by the patient: amount of prescriptions, history of non-adherence, difficulties in drugs consumption, presence of possible concurrent risks (falls, confusion, delirium, etc.), criticalities of the context.

viii) You must plan the discharge since the entrance of the person in the hospital and, according to the global evaluation (clinical, functional, socio-economical and related to the family), you must identify the cases of difficult discharge. You must identify and start the internal resources of the fam- ily and the one available in the territory in order to maintain the care continuity.

ix) You must identify during the admission in the hospital the educational needs related to the health management of the patient, of his family and of his caregivers. You must start educational interventions aimed to the therapy and diet self-management, to the use of aids, and to the untimely recognition of complications. You must provide guidance on the behavior to adopt and on the people to call for help, on processes and dates of the post-discharge, and on the active or to activate house services.

x) You must abstain from invasive care procedures during the patient's last stages of life. You must select the interventions to carry out in order to guarantee his dignity, life quality and the symptoms management, in particular an effective pain control.

\section{References}

1. Federazione Nazionale IPASVI. Codice deontologico dell'infermiere; 2009.

2. Ministero della Sanità. Decreto ministeriale 14 settembre 1994, n. 739. Regolamento concernente l'individuazione della figura e del relativo profilo professionale dell'infermiere. G.U. n. 6, 9/01/1995. Available from: http://www.ipasvi.it/archivio_news/leggi/179/DM14099 4n739.pdf

3. D'Amore F. The doctor and the patient: doing too much or too little. Ital J Med 2013;7:e22.

4. D'Ivernois JF, Gagnayre R. Educare il paziente - un approccio pedagogico. Milano: McGraw Hill; 2009.

5. Agenzia Sanitaria e Sociale Regionale, Area Accreditamento e Qualità, Regione Emilia Romagna. Sicurezza nella terapia farmacologica "Processo di ricognizione e di riconciliazione farmacologica per una prescrizione corretta e sicura"; 2011. Available from: http://www.saluter.it/documentazione/rapporti/sicurezza_farmacologica_2.pdfAccessed: 21/03/2014.

6. Shepperd S, McClaran J, Phillips CO, et al. Discharge planning from hospital to home. Cochrane Database Syst Rev 2010;(1):CD000313.

7. Costantini M, Borreani C, Grubich S. Migliorare la qualità delle cure di fine vita. Un cambiamento possibile e necessario. Trento: Erickson; 2009.

8. Registered Nurses'Association of Ontario (RNAO). End of life during the last days and hours; 2011. Available from: http://rnao.ca/bpg/guidelines/endoflife-care-during-last-days-and-hours Accessed: 1/03/2014.

9. Beccaro M, Costantini M. Actual and preferred place of death of cancer patients. Results from the Italian Survey of the Dying of Cancer (ISDOC). J Epidemiol Comm Health 2006;60:412-6.

10. Campanini M, Gussoni G, Silingardi, et al. Fattori di rischio per tromboembolismo venoso e profilassi nei pazienti ricoverati in medicina interna: analisi dallo studio FADOI GEMINI. Ital J Med 2010;4:23-31. 